\title{
What Are the Social Responsibilities of Banks?
}

\author{
Ian R. Harper
}

I $\mathrm{n}$ a discussion paper recently released by the Prices Surveillance Authority, Dr Ian Manning, of the National Institute of Economic and Industry Research, argues that the social responsibilities of banks warrant their being obliged by regulation to provide 'basic banking' services free of charge to the poor (Manning, 1995:21).

In Dr Manning's view, the imposition of account-keeping and transactions charges on bank accounts held by the poor is inefficient because some poor people will be induced to leave the banking system, thus obliging the community to forgo the benefits of 'universal banking' (akin in Dr Manning's opinion to universal primary education). It is also inequitable because those poor people who do retain bank accounts will spend a disproportionately high share of their limited incomes on bank fees and charges as compared with the rich.

\section{Economics and Morality}

Dr Manning begins his argument by asserting that banks, like the business community in general, have social responsibilities. He seems to believe that this view is somehow controversial or at variance with the principles of 'economic rationalism'. Yet there is no warrant in economic theory, certainly not in the general equilibrium theory that he is at pains to decry, for immoral or anti-social behaviour on the part of economic agents, be they firms, individuals or governments.

General equilibrium theory has nothing to say on the subject of morality or society: it is purely and simply an abstract theory of economic behaviour. Economic theory takes society and morality as given. It is solely concerned with the design of institutions and policies that maximise the economic welfare of humankind. To remark that this ignores the social and moral dimensions of human existence is a mere banality. Enabling human beings to realise their full potential requires social, moral, spiritual as well as economic progress.

The principles of economics apply whatever the social or moral context. They are directed to the task of providing for the material needs of humankind in a manner which makes most efficient use of limited material resources. Without moral guidance, such principles are perfectly capable of generating systems that produce material welfare at the expense of the moral or social good. Slavery, for example, is an efficient form of economic organisation, and so, to a lesser extent, is child labour. Economics qua economics is unlikely to condemn these activities. They are rightly shunned by civilised human beings on the grounds that they are morally and socially repugnant. The civilised mind does not hesitate to elevate the moral and social good above the material good when the former clearly outweighs the latter. 
Economic theory identifies the modern business corporation as an efficient instrument for the creation of material wealth which is in turn highly correlated with material welfare. To say this is conspicuously not to say that economics restricts the role of the business corporation to the creation of material wealth. Economics simply has nothing to say about the wider social responsibilities of business beyond observing that such corporations generally produce less material wealth when they are obliged to pursue non-economic objectives. In particular, economics identifies governments and private charities as superior instruments for the redistribution (as opposed to the creation) of material wealth.

The recognition that economic processes must be brought within the wider purview of morality and society is as least as old as Adam Smith, whose Wealth of Nations was preceded by his Theory of Moral Sentiments. Smith recognised that the moral quality of the outcome of economic processes is governed by the moral quality of the agents, including the civil authorities.

Clearly, business corporations have social responsibilities, as do individuals and governments. This is recognised by the business community, whose mission statements and codes of conduct are replete with references to duties to clients, staff and shareholders, and whose public relations departments are kept busy dispensing charitable donations to hospitals, schools and relief organisations.

\section{Techniques of Redistribution}

Where then is the evidence that the business community in general, or banks in particular, deny their social responsibilities or fail to honour them? According to Dr Manning, the fact that banks impose fees and charges on bank accounts held and operated by the poor proves that banks are indeed socially irresponsible. His solution is to allow the moral weight of civilised society to bear upon the banks and oblige them to offer such services to the genuinely indigent either free of charge or heavily discounted.

If Dr Manning is right that imposing charges on bank accounts operated by the poor is socially irresponsible, the government itself stands condemned along with the banks. The Financial Institutions Duty and Bank Account Debit Tax levied by government is more onerous than any of the fees levied by banks. Moreover, while the banks grant some exemptions to disadvantaged groups, including aged and war veteran pensioners and students, the government offers no such exemptions from its own bank account taxes.

Research conducted by the banks (National Australia Bank, 1995) shows that bank account taxes are a far greater source of customer irritation than fees and charges. If one felt the need to lessen the burden of various imposts on bank accounts held by the poor, one would not start with bank fees and charges but with the government's own regressive bank account taxes.

The broader response to Dr Manning is to point out that forcing the banks to dispense charity is inefficient. Banks, like other business corporations, are designed to produce wealth, not to redistribute it. This is not to say that their creation of wealth should ignore the claims of social and moral propriety. But it is another 
thing entirely to ask banks to undertake a social responsibility for which they are not properly suited.

If one is genuinely concerned to alleviate the plight of the poor, one is surely keen to ensure that the redistribution of wealth takes place at minimum cost. The more wealth that is wasted during the process of redistribution, the less is available to be redistributed.

If banks become less efficient in creating wealth as a result of having to meet social objectives imposed upon them, society at large, including the poor, is the worse for it. The less wealth banks create, the less tax they pay and the less money there is available for the general alleviation of poverty above and beyond the provision of banking services. The poor also need medical services, shelter and food.

Indeed, consider the case of food. If Dr Manning is so concerned for the welfare of the poor, why does he start with banking services? Surely charging the poor for the provision of food displays an equally lamentable lack of social responsibility on the part of supermarket chains and their suppliers. Why not protest that ColesMyer or Woolworths should be forced to dispense food parcels to the poor free of charge?

Precisely the same issue arises with the provision of public utility services like water, electricity and gas. A good case can be made that charges for the provision of such basic necessities are regressive and that the poor should be supplied free of charge. But even governments do not oblige public utilities to supply services to the poor at discounted rates. It is too inefficient, and governments are concerned to husband society's scarce resources for the benefit of all citizens, rich and poor alike.

Governments negotiate 'community service obligations' (CSOs) with public utilities under which the enterprises supply services to those nominated by the government and the government foots the bill. This approach has the great advantage that the enterprise is allowed to price its product so as fully to recover the costs of production. This ensures that its resources are used efficiently. Furthermore, by holding an auction amongst competing public utilities (electricity distribution companies, for example), the government can ensure that the CSO is fulfilled at least cost to the public purse.

Another great benefit is that the amount of the subsidy is explicitly revealed in the government budget and not hidden in the accounts of public utilities. The public can therefore decide whether to increase or decrease the subsidy according to its sense of social responsibility.

Surely this is an appropriate model for the provision of basic banking services to the poor. If governments see fit to meet their social obligations to provide the poor with electricity and water in this fashion, why not banking services as well? This would allow banks to concentrate on the task for which they were designed: the creation of new wealth through financial intermediation. Part of this new wealth would find its way into government hands in the form of taxation and then be available to purchase banking services and other necessities on behalf of the deserving poor. 
Banks fulfil their primary social responsibility by creating wealth efficiently through the provision of financial intermediation services. In this process, they can, of course, be expected to meet community expectations of moral probity and good corporate citizenship. The efficient way to provide banking services for the poor is to follow the example of the public utilities and negotiate community service obligations for the provision of basic services at public expense.

\section{Bank Supervision and Regulation}

Nor is it an answer to say that banks enjoy privileged status within the community by virtue of their relationship with the Reserve Bank of Australia. Dr Manning seems to imply (1995:19) that this relationship confers net benefits upon the banks which they should be obliged to 'pay for' by extending free services to the deserving poor: a modern variant of noblesse oblige. But the Reserve Bank supervises banks; it does not protect them. Banks who make unwise commercial decisions are allowed to fail, as the disastrous experience of the former State Bank of Victoria illustrated so poignantly. The Reserve Bank has no legal authority to protect banks from their mistakes. It is obliged to protect bank depositors to the best of its ability but even then offers no indemnity against loss of either principal or interest.

In any case, banks are obliged to meet Reserve Bank guidelines in respect of capital and liquidity adequacy, to obey directives issued from time to time by the Bank and to comply with Reserve Bank reporting requirements. These regulatory burdens offset any 'privileges' that bank status might confer. If the balance were markedly in favour of the privileges, entry into the banking industry would be much more popular that it is.

While new banks do appear from time to time, if, as Dr Manning implies, banks are the beneficiaries of substantial public subsidies (albeit implicit), the licensing of new banks would be a torrent, not a trickle.

\section{References}

Manning, I. (1995), The Social Responsibilities of Banks, Prices Surveillance Authority, Melbourne (Discussion Paper No. 6).

Natonal Australia Bank (1995), Submission to the Prices Surveillance Authority on the inquiry into fees and charges imposed on retail transaction accounts by banks and other financial institutions, Melbourne.

Ian Harper is Professor and Director of the Ian Potter Centre for International Finance at the Melbourne Business School within the University of Melbourne. 